\title{
Belowground nitrogen dynamics in relation to hurricane damage along a tropical dry forest chronosequence
}

\author{
Niles J. Hasselquist • Louis S. Santiago • \\ Michael F. Allen
}

Received: 6 March 2009/Accepted: 14 September 2009/Published online: 7 November 2009

(C) The Author(s) 2009. This article is published with open access at Springerlink.com

\begin{abstract}
Understanding and predicting the responses of plant communities to multiple overlapping disturbances remains a challenging task. Hurricane Wilma represents a large, yet infrequent type of disturbance that was superimposed on an existing disturbance gradient of time since fire. We examined disturbance and recovery patterns in response to these overlapping disturbances by measuring how canopy structure, fine roots, mycorrhizae, and soil nitrogen dynamics, varied along a fire chronosequence in the 2 years after Hurricane Wilma. Hurricane damage increased canopy openness in all seral stages. In the early-seral stage, canopy openness returned to prehurricane conditions within 2 years, whereas canopy openness in the late-seral stage remained significantly higher throughout the study. We observed no significant change in root length density in the early- and mid-seral stages. However, in the late-seral stage, root length density was significantly reduced immediately after the hurricane and remained so 2 years
\end{abstract}

N. J. Hasselquist $(\varangle) \cdot$ L. S. Santiago · M. F. Allen Center for Conservation Biology, University of California, Riverside, Riverside, CA 92521, USA

e-mail: nhass001@ucr.edu

N. J. Hasselquist - M. F. Allen

Plant Pathology and Microbiology, University of

California, Riverside, Riverside, CA 92521, USA

\section{S. Santiago}

Botany \& Plant Science, University of California, Riverside, Riverside, CA 92521, USA after the hurricane. In the late-seral stage, we also observed a significant reduction in percent soil nitrogen and a significant increase in soil nitrogen isotopic composition $\left(\delta^{15} \mathrm{~N}\right)$ values, indicating a loss of soil nitrogen. In contrast, in the early- and midseral stages, there were no significant changes in percent nitrogen or soil $\delta^{15} \mathrm{~N}$ values. Results from this study suggest that forest fire disturbance history influences responses to hurricane damage. Moreover, feedbacks between aboveground and belowground processes have the potential to influence forest recovery.

Keywords Large-infrequent disturbance . Hurricane Wilma · Nitrogen dynamics . Secondary succession $\cdot$ Stable isotopes . Yucatan Peninsula

\section{Introduction}

Understanding and predicting responses to and subsequent recovery of plant communities after large, infrequent disturbances remains a critical and challenging task. Hurricanes are an example of large, infrequent disturbances causing defoliation as well as damaging and killing trees through uprooting and stem breakage (Brokaw and Walker 1991; Tanner et al. 1991; Walker 1991; Whigham et al. 1991; Zimmerman et al. 1996). Hurricane impact on 
aboveground forest structure is well documented and varies considerably across the landscape (Weaver 1986; Boucher 1990; Bellingham 1991; Tanner et al. 1991; Yih et al. 1991; Lugo and Scatena 1995). Generally, the importance of large, infrequent disturbances in shaping landscapes and ecosystems has been studied from an aboveground perspective (Turner and Dale 1998). However, changes in belowground processes, such as nutrient cycling, root growth and mycorrhizal colonization can have profound effects on tree growth and forest regeneration (Janos 1980a; Allen 1991; Johnson and Wedin 1997; Kiers et al. 2000; Allen et al. 2003a; Hodge 2004) but have rarely been studied. Understanding the response and recovery of belowground processes after hurricane damage may, in part, help explain the recovery of aboveground forest structure.

Although less evident than aboveground processes, hurricane damage can have pronounced effects on belowground processes, including trace gas fluxes (Steudler et al. 1991; Vargas and Allen 2008), soil nutrients (Scatena et al. 1993), and fine roots (Parrotta and Lodge 1991; Silver and Vogt 1993; Beard et al. 2005). Parrotta and Lodge (1991) showed that more than 1 year may be required for the recovery of fine roots to pre-hurricane levels. In addition to fine roots, mycorrhizal associations between plant roots and fungi may also be adversely affected by hurricane disturbances (Vargas et al. 2009). Because of the loss in stand leaf area, photosynthetic capacity is reduced as a result of the hurricane, simultaneously reducing the carbon supply necessary to support mycorrhizal fungi. However, we know little about the effect of hurricane disturbances on mycorrhizal associations because of the scarcity of studies.

Tropical forests are dominated by trees that form arbuscular mycorrhizal (AM) associations (Read 1991; Allen et al. 1995; Treseder and Cross 2006), and numerous studies have shown the importance of AM fungi for the growth of many tropical trees (Janos 1980a, b; Huante et al. 1993; Fisher et al. 1994; Kiers et al. 2000; Allen et al. 2003a). AM fungal taxa and fungal activity vary among different seral stages (Janos 1980b; Allen et al. 2003a) and with different soil conditions caused by disturbance history (Allen et al. 2005). Nevertheless, numerous studies have shown that fine roots and mycorrhizal fungi are essential for rapid and efficient cycling of nutrients in environments where the potential for nutrient leaching is high (Went and Stark 1968; Stark 1971; Stark and Spratt 1977; Stark and Jordan 1978; Cuevas and Medina 1988). Changes in root and mycorrhizal dynamics after a hurricane could therefore have pronounced effects on the ability of trees to absorb the pulse of nutrients frequently observed after a hurricane disturbance and mitigate ecosystem nutrient losses.

Hurricane damage also causes a pulse of litterfall (Lodge et al. 1991; Whigham et al. 1991; Allen et al. 2007), which can affect nutrient cycling (Lodge et al. 1991; Lodge and McDowell 1991; Steudler et al. 1991). This litterfall often contains higher than normal concentrations of certain nutrients because there is no opportunity for retranslocation of nutrients to occur before leaf abscission (Blood et al. 1991; Frangi and Lugo 1991; Lodge et al. 1991). For instance, in Puerto Rico the nitrogen content of litterfall after Hurricane Hugo was 1.3-2.2 times the mean annual litterfall (Lodge and McDowell 1991). Such sudden, large additions can lead to increased ammonium availability, net nitrogen mineralization rates, and an increase in nitrate concentrations in the soil, which in turn can lead to nitrogen loss via leaching, volatilization, and denitrification (Steudler et al. 1991).

Natural abundance of ${ }^{15} \mathrm{~N}$ in soil and plant pools provides a useful tool for studying nitrogen dynamics in forested ecosystems (Nadelhoffer and Fry 1994; Martinelli et al. 1999; Amundson et al. 2003; Templer et al. 2007). Although isotopic values result from many interacting processes (Handley and Scrimgeour 1997), isotopic data often point to particular mechanisms that are otherwise difficult to measure. In ecosystems that are characterized by high nitrogen availability (e.g., Aber et al. 1989), there are a number of fractionating processes that result in high soil $\delta^{15} \mathrm{~N}$ values. Microbes discriminate against ${ }^{15} \mathrm{~N}$ during decomposition, mineralization (Nadelhoffer and Fry 1994), nitrification (Nadelhoffer and Fry 1994; Högberg 1997; Handley and Raven 1992) and denitrification (Piccolo et al. 1996). As soil nitrogen increases, soil $\delta^{15} \mathrm{~N}$ values increase because of fractionating pathways of nitrogen loss from the ecosystem such as leaching or gaseous loss (Agren and Bosatta 1988; Aber et al. 1989; Stoddard 1994; Peterjohn et al. 1996; Martinelli et al. 1999). Forested ecosystems with relatively open nitrogen cycles are therefore characterized by enriched soil $\delta^{15} \mathrm{~N}$ values 
due to loss through fractionating pathways compared to systems with relatively closed nitrogen cycles that are depleted in ${ }^{15} \mathrm{~N}$ (Austin and Vitousek 1998; Schuur and Matson 2001).

Seasonally dry tropical forests on the Northern Yucatan Peninsula are subject to anthropogenic disturbances such as land clearing or agriculture conversion (Gómez-Pompa 1992; Gómez-Pompa et al. 2003) as well as natural disturbances such as hurricanes and fire (Boose et al. 2003; Whigham et al. 2003). Consequently, these disturbances create a patchy mosaic of different seral stages undergoing secondary succession. The effect of multiple disturbances in these forests may not be additive, but synergistic in nature, causing non-linear changes in successional trajectories or ecosystem recovery patterns. In this study, we combined soil nitrogen and stable isotope measurements with measurements of root and mycorrhizal dynamics to examine changes in belowground processes after a major hurricane on the Northern Yucatan Peninsula. Our main objective was to examine the immediate and short-term recovery of belowground processes after a hurricane along a chronosequence of secondary succession to better understand how multiple disturbances may influence the recovery of forest structure and belowground processes.

\section{Materials and methods}

Study site

The study was carried out at El Eden Ecological Reserve (Gómez-Pompa et al. 2003), located in the northeastern corner of the Yucatan Peninsula, Mexico $\left(21^{\circ} 12.61^{\prime} \mathrm{N}, 87^{\circ} 10.93^{\prime} \mathrm{W}\right)$. The Reserve has 2,500 -ha of protected landscape in which 800 ha represent mature forest and the remaining area is secondary forest. The landscape is flat, with an elevation $6 \mathrm{~m}$ above sea level, and occurs on limestone bedrock. Soils and climate are similar across the Reserve (see Gómez-Pompa et al. 2003). Soils are shallow (depth $<20 \mathrm{~cm}$ ), with mean soil organic matter of $30 \%$ and a bulk density of $0.35 \mathrm{~g} / \mathrm{cm}^{3}$. The reserve receives an average of $1,650 \mathrm{~mm}$ of annual precipitation with a wet season from June to October. The dry season is from December to May when precipitation is $<100 \mathrm{~mm}$ per month. The mean annual temperature is $24.2^{\circ} \mathrm{C}$, and mean annual soil temperature at $10 \mathrm{~cm}$ depth is $23.2^{\circ} \mathrm{C}$.

The vegetation of the Reserve is described in Schutlz (2005), and is a mosaic of successional vegetation. Over the past four decades, severe fires have crossed portions of the Reserve (Allen et al. 2003b; Boose et al. 2003; Whigham et al. 2003). During these burns the standing vegetation was consumed and the bedrock was largely exposed due to combustion of the organic soil (Allen et al. 2003a). For this study, we selected forest stands that burned during the dry season of 1999 and 1989. The forest stand that burned during the dry season of 1999 did not burn in 1989. We also selected a late successional forest stand within the protected area of the reserve with no evidence of fire, human or hurricane disturbance for more than 60 years. Thus, we have selected three different forest stands representing a chronosequence of secondary succession ranging in age from an area burned 9 years ago (early-seral stage), an area burned 18 years ago (mid-seral stage) to an area that has not been disturbed for more than 60 years (lateseral stage). All seral stages are greater than 500 ha and are located within a distance of $5 \mathrm{~km}$ of each other. Seral stages have a large overlap in tree species with little or no apparent patch structure within the seral units. We assumed that any structural and functional differences among sites (Table 1) are related to time since fire rather than their spatial location because there is no slope or relief difference in the landscape. Unfortunately, we did not determine soil texture among the different seral stages. We know that Mayans cultivated the area that is now the Reserve during the early classic period (1,500 years ago), but land use since has been minimal, with only selective tree harvesting in the late 1800 s and early 1900s (Gómez-Pompa et al. 2003). For additional information about the Reserve see Allen et al. (2003a, b) and Vargas et al. (2008).

\section{Hurricane Wilma}

On 21 October 2005 Hurricane Wilma made landfall crossing the island of Cozumel and onto the Yucatan Peninsula as a Category IV storm on the SaffirSimpson scale, and emerged over the Gulf of Mexico on October 23 as a Category II hurricane. While in the Caribbean, Hurricane Wilma was the most intense hurricane recorded in the Atlantic basin with a 
Table 1 Stand characteristics of tree species found among the three seral stages undergoing different stages of secondary succession on the Northern Yucatan Peninsula, Mexico

\begin{tabular}{|c|c|c|c|c|c|c|}
\hline Seral stage & $\begin{array}{l}\text { AGB } \\
(\mathrm{mg} / \mathrm{ha})\end{array}$ & $\begin{array}{l}\text { Soil organic } \\
\text { matter }(\%)\end{array}$ & $\begin{array}{l}\text { Percent legumes } \\
\text { by species }{ }^{\text {a }}(\%)\end{array}$ & AM status ${ }^{\mathrm{b}}$ & EM status ${ }^{c}$ & $\begin{array}{l}\text { Canopy } \\
\text { height }(\mathrm{m})\end{array}$ \\
\hline Early & $20.1 \pm 2.1$ & $28.8 \pm 1.6$ & 28 & Present & Absent & 4 \\
\hline Mid & $62.8 \pm 2.8$ & $48.12 \pm 3.9$ & 17 & Present & Few & 8 \\
\hline Late & $143.9 \pm 6.5$ & $59.8 \pm 3.0$ & 16 & Present & Present & 14 \\
\hline
\end{tabular}

Means and standard errors of aboveground biomass (AGB) and soil organic matter are from data collected by Vargas et al. (2008)

${ }^{a}$ Based on the presence/absence or legume trees along line transects within each seral stage

${ }^{b}$ Based on arbuscular mycorrhizal colonization of plant roots

c Based on taxonomic affiliation and stable isotope composition of fungal sporocarps

minimum barometric pressure of $882 \mathrm{mbar}$ and maximum winds of $295 \mathrm{~km} / \mathrm{h}$. As the eye of the hurricane crossed directly over our study site the barometric pressure dropped from 1,010 to 970 mbar with sustained winds between 190 and $210 \mathrm{~km} / \mathrm{h}$ (Allen et al. 2007). The Reserve received over $1,500 \mathrm{~mm}$ of precipitation during this 3 days period and soils remained saturated for nearly 50 days.

\section{Aboveground hurricane damage}

In September 2005, one month before the hurricane, we established three parallel $60 \mathrm{~m}$ transects randomly in each of the early-, mid- and late-seral stages. Transects were oriented in a north to south direction and were position far enough into each seral stage to avoid any border effect. The minimum distance between two transects was $150 \mathrm{~m}$. Along each transect we randomly selected two locations where both aboveground and belowground measurements were taken resulting in six locations in each seral stage. At each location, we took hemispherical photographs below the forest canopy at $1 \mathrm{~m}$ height and calculated percent canopy openness using Gap Light Analyzer V2.0 (Canham 1988). Hemispherical photographs were taken at the same location during the third week of December 2005 (2 months after) to determine the amount of hurricane damage on canopy openness, and again in September 2007 (2 years after) to determine recovery of the canopy.

\section{Effects of hurricane damage on soil factors}

At the same places where hemispherical photographs were taken, soil samples were collected by inserting a $4.5 \mathrm{~cm}$ diameter metal soil corer until we encountered the limestone bedrock (usually $<10 \mathrm{~cm}$ in depth) for a total of six soil samples per seral stage. Soil samples were collected in September 2005 (pre-hurricane), December 2005 (2 months after Hurricane Wilma), September 2006 (1 year after), and again in September 2007 (2 years after). Samples were air dried and transported to the University of California, Riverside where they were stored at $-20^{\circ} \mathrm{C}$ prior to starting laboratory analyses. Fine roots (live roots $<2.0 \mathrm{~mm}$ in diameter) from individual cores were sorted by hand and rinsed free of organic matter with deionized water. For each sample, fine root length density was determined using the line intersection method (Newman 1966). Fine roots were then divided into two subgroups for various measurements. One sub-sample was used to determine percent AM colonization (see description below), whereas the other sub-sample was dried $\left(70^{\circ} \mathrm{C}, 48 \mathrm{~h}\right)$ and ground to a fine powder for chemical analysis. We choose to examine root $\delta^{15} \mathrm{~N}$ values, as opposed to foliar $\delta^{15} \mathrm{~N}$ values, because we expected a stronger relationship between root $\delta^{15} \mathrm{~N}$ values and soil nitrogen cycling rates since there is a more direct connection between roots and ${ }^{15} \mathrm{~N}$-enrichment processes driven by nitrification, i.e., fewer plant processes occur before the nitrogen is assimilated, and possibly discriminated against in plant tissues (Handley and Raven 1992). Root carbon and nitrogen concentrations and isotopic composition of carbon $\left(\delta^{13} \mathrm{C}\right)$ and nitrogen $\left(\delta^{15} \mathrm{~N}\right)$ were determined with an elemental analyzer (Model ANCA-SL, Europa Scientific, Ltd, Crewe, UK) connected to a continuous flow isotope ratio mass spectrometer (Model 20/20, Europa Scientific) at the Center for Stable Isotope Biogeochemistry of the University of California, Berkeley. Stable isotope abundances are reported as: $\delta^{15} \mathrm{~N}$ or $\delta^{13} \mathrm{C}(\%)=\left(R_{\text {sample }} / R_{\text {standard }}-1\right) \times 1000$, 
where $R={ }^{15} \mathrm{~N} /{ }^{14} \mathrm{~N}$ or ${ }^{13} \mathrm{C} /{ }^{12} \mathrm{C}$ of the sample and reference standard (atmospheric $\mathrm{N}_{2}$ and PeeDee beleminite-C, respectively). The standard deviation of isotopic measurements of the internal standards used was typically $<0.2 \%$ for both $\delta^{15} \mathrm{~N}$ and $\delta^{13} \mathrm{C}$.

Mycorrhizal infection

Roughly $10 \mathrm{mg}$ of fine roots from each sample was used to determine AM colonization. We did not distinguish among roots of different plant species because of the large number of species present in these forests. Roots were cleared in $10 \% \mathrm{KOH}\left(90^{\circ} \mathrm{C}\right.$, $1 \mathrm{~h})$ and $3 \% \mathrm{H}_{2} \mathrm{O}_{2}\left(90^{\circ} \mathrm{C}, 20 \mathrm{~min}\right)$, acidified in $1 \%$ $\mathrm{HCl}$ for $10 \mathrm{~min}$, stained with $0.05 \%$ Trypan Blue $\left(90^{\circ} \mathrm{C}, 1 \mathrm{~h}\right)$ and then de-stained in acidified glycerol (Koske and Gemma 1989). Approximately thirty $1 \mathrm{~cm}$ root fragments were mounted on glass slides with PVLG (polyvinyl lactoglycerol) medium and microscopically assessed for the presence of mycorrhizal hyphae using the magnified intersection method (McGonigle et al. 1990). At least 100 intersections were scored for each sample.

Statistical analysis

Data sets were tested for normality with a one-sample Kolmogorov-Smirnov test. Percent AM colonization was the only data that was not normally distributed; therefore, it was arcsine transformed to meet the assumptions of analysis of variance. Measurements taken in September 2005 were subjected to a one-way ANOVA to detect significant $(P<0.05)$ differences among seral stages before the hurricane. Within each seral stage, repeated measures ANOVA was used to test for changes in measured variables among sampling dates. All statistical analyses were performed using SPSS statistical software (SPSS Inc., v16.0, 2007).

\section{Results}

Aboveground damage

One month before Hurricane Wilma made landfall on the Northern Yucatan Peninsula in October 2005, percent canopy openness was significantly greater in the early-seral forest compared to mid- and late-seral

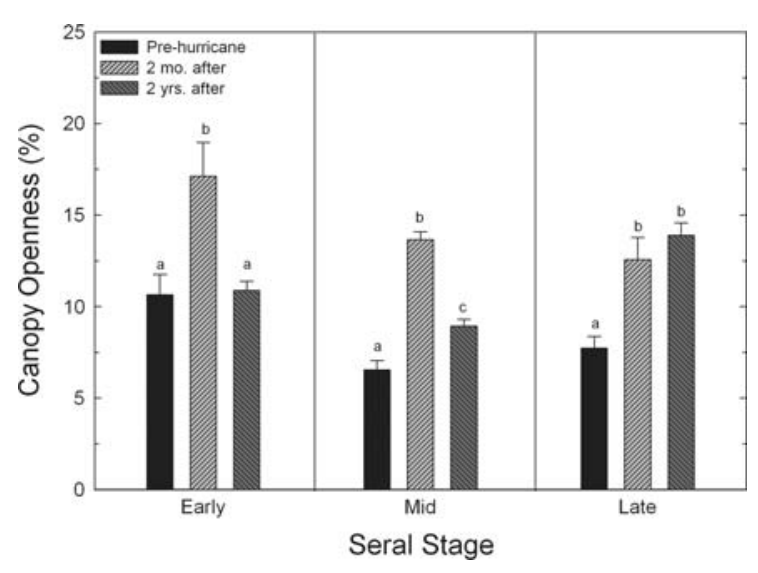

Fig. 1 Mean $( \pm$ SE) percent canopy openness before and after Hurricane Wilma. As the eye of the hurricane crossed directly over our research site on 22 October 2005 the barometric pressure dropped from 1010 to 970 mbar with sustained winds between 190 and $210 \mathrm{~km} / \mathrm{h}$. Different letters indicate significant $(P<0.05)$ differences among sampling dates within each seral stage

forests $\left(F_{2,17}=7.18, P<0.01\right)$. Immediately following the hurricane there was a significant increase in percent canopy openness in all forest types (Fig. 1; $P<0.01)$. However, aboveground canopy recovery differed among seral stages (Fig. 1). In the early-seral stage, percent canopy openness returned to prehurricane levels within 2 years after the hurricane (Fig. 1), whereas canopy openness in the late-seral stage remained significantly higher than pre-hurricane levels 2 years after the hurricane $\left(F_{2,10}=16.17\right.$, $P=0.001)$.

Hurricane damage on soil factors

Before the hurricane we detected no differences in fine root length density among the different seral stages $\left(F_{2,17}=0.79, P=0.47\right)$. However, the immediate response and short-term recovery of fine roots differed among seral stages (Fig. 2a). In the late-seral stage, fine root length density was significantly reduced 1 year after the hurricane and remained reduced 2 years after the hurricane $\left(F_{3,15}=5.29\right.$, $P=0.01)$. In contrast, both the early-and mid-seral stages showed no significant difference in fine root length density throughout the study (Fig. 2a).

No significant difference in AM colonization was detected among seral stages before the hurricane $\left(F_{2,17}=0.87, P=0.44\right)$. However, when comparing 


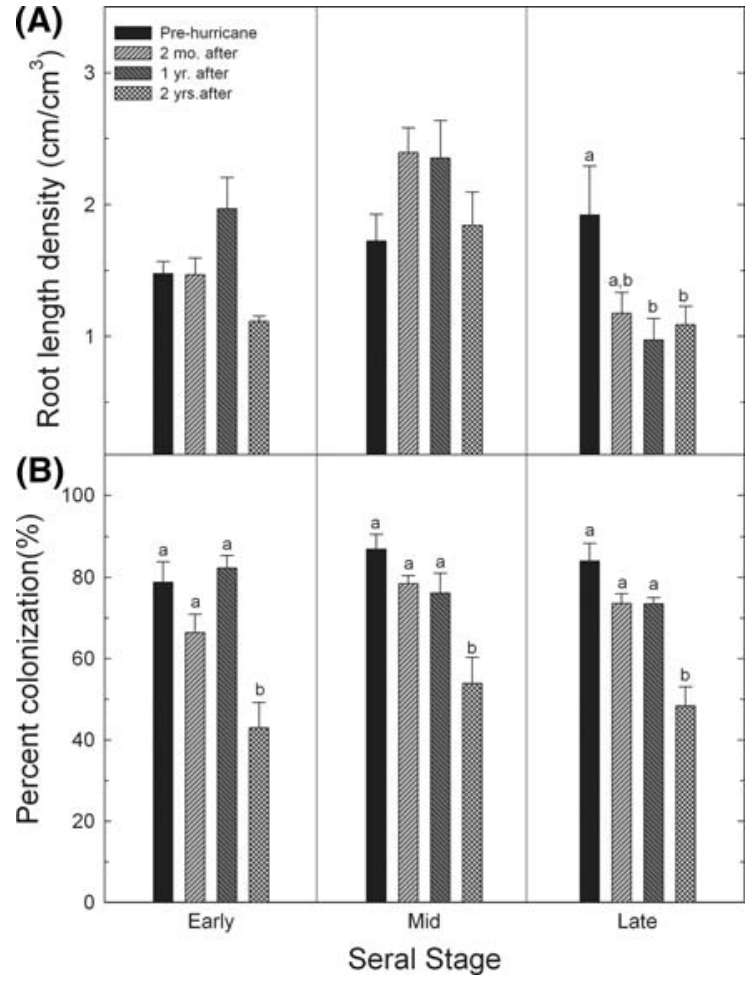

Fig. 2 Immediate impact and short-term recovery of a root length density and $\mathbf{b}$ arbuscular mycorrhizal colonization within different seral stages after Hurricane Wilma. Different letters indicate significant $(P<0.05)$ differences among sampling dates within each seral stage (means $\pm \mathrm{SE}, N=6$ )

among all seral stages we observed a significant reduction in AM colonization immediately following the hurricane $\left(F_{3,51}=38.21, P=0.05\right)$. One year after the hurricane AM colonization return to prehurricane levels $(P=0.18)$. Interestingly, AM colonization was severely reduced 2 years after the hurricane compared to pre-hurricane values $(P<$ 0.001 ), with average colonization of $48.42 \% \pm 3.38$ (Fig. 2b).

Percent nitrogen in plant roots was not significantly different among seral stages before the hurricane (Fig. 3a, $F_{2,17}=2.79, P=0.09$ ). We detected no change in percent root nitrogen among sampling dates (Fig. 3a). Root $\delta^{15} \mathrm{~N}$ values differed significantly among seral stages before the hurricane $\left(F_{2,17}=8.25, P<0.01\right)$. Roots in the early-seral stage had higher $\delta^{15} \mathrm{~N}$ values compared to roots in both the mid-and late-seral stages. We detected no change in root ${ }^{15} \mathrm{~N}$ values among sampling dates (Fig. 3b).
Percent carbon in plant roots was not significantly different among seral stages before the hurricane (Fig. 3c, $F_{2,17}=2.30, P=0.14$ ). When comparing among all seral stages, we detected a significant difference among sampling dates $\left(F_{3,51}=3.40\right.$, $P=0.03)$. Samples collected 2 years after the hurricane were significantly lower than pre-hurricane samples $(P=0.04)$. Before the hurricane we detected no significant differences in root $\delta^{13} \mathrm{C}$ values among seral stages $\left(F_{2,17}=1.67, P=0.22\right)$, nor did we find differences among sampling dates (Fig. 3d).

Soil nitrogen differed significantly among all seral stages before the hurricane $\left(F_{2,17}=45.08, P<\right.$ $0.001)$. Percent soil nitrogen was lowest in the early-seral stage $(1.06 \% \pm 0.10)$, intermediate in the mid-seral stage $(2.22 \% \pm 0.17)$, and highest in the late-seral stage $(2.69 \% \pm 0.09)$. The immediate response and short-term recovery of soil nitrogen differed among seral stages (Fig. 4a). In the late-seral stage, percent soil nitrogen was significantly reduced immediately after the hurricane and remained reduced 2 years after the hurricane $\left(F_{3,15}=10.02\right.$, $P<0.01)$. In contrast, in the mid-seral stage the percentage of soil nitrogen was not significantly lower than pre-hurricane values until 2 years after the hurricane $\left(F_{3,15}=6.89, P<0.01\right)$. In the early-seral stage we detected no significant change in soil nitrogen $\left(F_{3,15}=1.53, P=0.25\right)$. Before the hurricane soil $\delta^{15} \mathrm{~N}$ values differed significantly among all seral stages $\left(F_{2,17}=102.05, P<0.001\right)$. Soil $\delta^{15} \mathrm{~N}$ values were lowest in the late-seral stage $(1.93 \%$ o \pm 0.10$)$, intermediate in the mid-seral stage $(2.92 \% \pm 0.24)$, and highest in the early-seral stage $(5.75 \% \pm 0.22)$. The immediate response and shortterm recovery of soil $\delta^{15} \mathrm{~N}$ values differed among seral stages (Fig. 4b). In the late-seral stage, soil $\delta^{15} \mathrm{~N}$ values significantly increased after the hurricane and remained higher 2 years after the hurricane $\left(F_{3,15}=6.03, P<0.01\right)$. In contrast, in the earlyand mid-seral stages we detected no significant change in soil $\delta^{15} \mathrm{~N}$ values throughout the study (Fig. 4b).

Percent soil carbon before the hurricane differed significantly among all seral stages $\left(F_{2,17}=55.42\right.$, $P<0.001)$. Percent soil carbon was lowest in the early seral stage $(9.40 \% \pm 1.06)$, intermediate in the mid-seral stage $(27.94 \% \pm 2.68)$, and highest in the late-seral stage $(33.74 \% \pm 0.74)$. The immediate response and short-term recovery of soil carbon 
Fig. 3 Immediate impact and recovery of a percent nitrogen, $\mathbf{b}{ }^{15} \mathrm{~N}$ values, $\mathbf{c}$ percent carbon, and $\mathbf{d}^{13} \mathrm{C}$ values from plant roots collected in early-, mid-, and late-successional forests. Samples were collected 1 month before (pre-hurricane), 2 months after, 1 year after, and 2 years after the pass of Hurricane Wilma. Different letters indicate significant $(P<0.05)$ differences among sampling dates within each seral stage (means $\pm \mathrm{SE}, N=6$ )

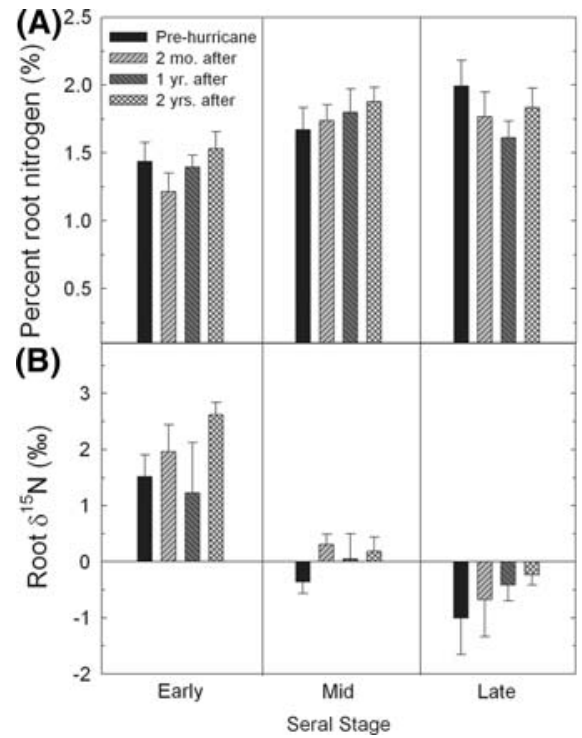

Fig. 4 Immediate impact and recovery a percent nitrogen, $\mathbf{b}{ }^{15} \mathrm{~N}$ values, $\mathbf{c}$ percent carbon, and $\mathbf{d}{ }^{13} \mathrm{C}$ values (mean $\pm \mathrm{SE}$ ) from soil collected in early-, mid, and late-successional forests. Samples were collected 1 month before (pre-hurricane), 2 months after, 1 year after, and 2 years after the pass of Hurricane Wilma. Different letters indicate significant $(P<0.05)$ differences among sampling dates within each seral stage (means $\pm \mathrm{SE}, N=6$ )

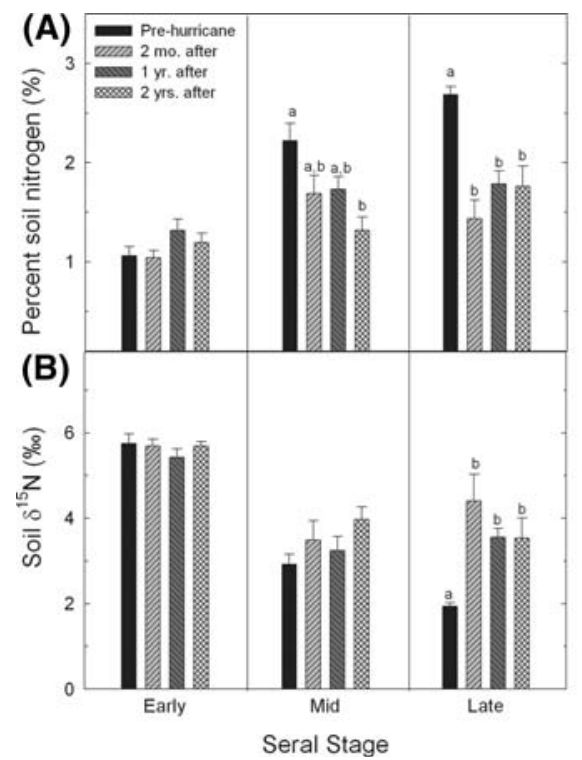

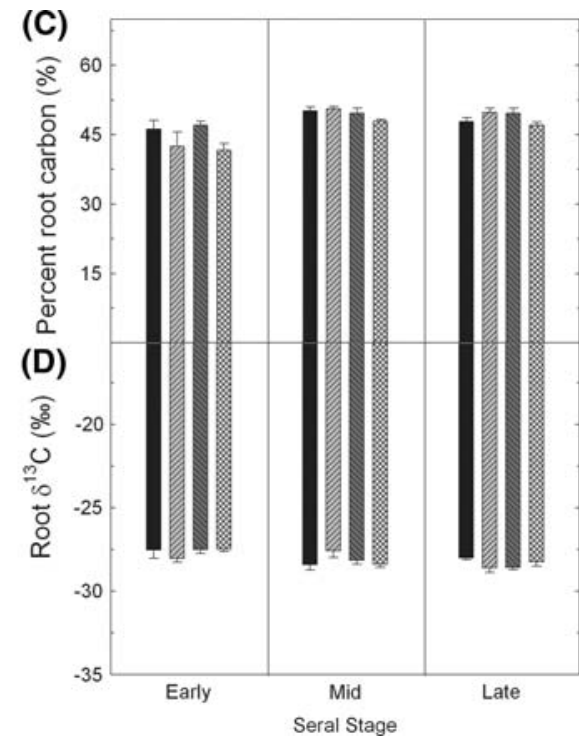

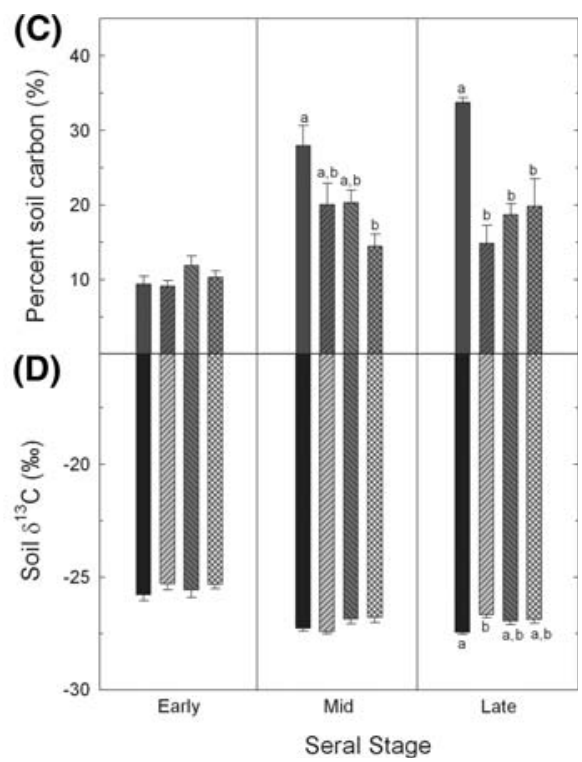

differed among seral stages (Fig. 4c). In the late-seral stage, soil carbon was significantly reduced after the hurricane and remained reduced throughout the study $\left(F_{3,15}=11.45, P<0.001\right)$. In the mid-seral stage the percentage of soil carbon 2 years after the hurricane was significantly lower than pre-hurricane $\left(F_{3,15}=\right.$ $6.78, P<0.01)$. In contrast, in the early-seral stage we detected no significant change in soil carbon $\left(F_{3,15}=1.21, P=0.34\right)$. Before the hurricane soil $\delta^{13} \mathrm{C}$ values in the early-seral stage were significantly higher than mid-and late-seral stages $\left(F_{2,17}=27.10\right.$, $P<0.001)$. In the early- and mid-seral stages we detected no significant change in soil $\delta^{13} \mathrm{C}$ values (Fig. 4d). However, in the late-seral stage soil $\delta^{13} \mathrm{C}$ values significantly increased immediately after the hurricane $\left(F_{3,15}=4.96, P=0.01\right)$.

\section{Discussion}

Results from this study suggest that large, infrequent disturbances can be an important force in creating the aboveground structure of seasonally dry tropical forests on the Northern Yucatan Peninsula. Moreover, 
the recovery of forest canopy after a large, infrequent disturbance is heavily influenced by prior site history (Foster et al. 1999; Uriate et al. 2004; Chazdon 2003; Thompson et al. 2007). We found early-and mid-seral stages to be more resilient to a hurricane disturbance, whereas the taller, late-seral forest (Table 1), with more biomass to lose, appeared more vulnerable. In addition to widespread defoliation, we also observed numerous broken braches in the late-seral stage after the hurricane, whereas the occurrence of broken braches in the early- and mid-seral stages was less common. Similarly, Pascarella et al. (2004) predicted that the effect of hurricanes on forest structure and ecosystem processes would be more pronounced in late-successional forests compared to early-successional forests as a result of increased structural diversity in older forest stands. We also demonstrated that changes in belowground processes are such that they may exert an extensive feedback on the recovery of aboveground forest canopy.

There were important differences in the immediate response and subsequent recovery of fine roots amongst the different seral stages. In both the earlyand mid-seral stages, we found no significant change in root length density following the hurricane. In contrast, root length density in the late-seral stage was significantly reduced and remained reduced 2 years after the hurricane. Such a reduction in fine roots can have pronounced affects on the ability of trees to absorb the pulse of nutrients from aboveground hurricane litterfall (Lodge et al. 1991). The loss of nitrogen, in particular, could be extremely important as high leaf nitrogen is critical for high levels of photosynthesis, and nitrogen not absorbed immediately could be lost through leaching and denitrification. Significant and prolonged reduction in fine roots could therefore limit the amount of nitrogen absorbed by plants, which in turn may help explain the arrested regeneration of aboveground canopy in the late-seral stage.

To our knowledge this is the first study to examine the effect of a hurricane disturbance on mycorrhizal associations. Previous studies have examined the response of AM associations to individual treefalls and reported small negative to no effects (Allen et al. 1998; Guadarrama and Alvarez-Sanchez 1999). Other studies have shown that defoliation and herbivory tend to reduce AM root colonization (Eom et al. 2001; Gange et al. 2002; Wearn and Gange 2007), but these studies are difficult to extrapolate to larger scale damage associated with hurricanes. Here, we observed a reduction in AM colonization immediately following Hurricane Wilma, indicating mycorrhizal associations are adversely affected by hurricane disturbances. Previously, Wearn and Gange (2007) explained the reduction in AM colonization due to herbivory as the result of foliage loss and the corresponding reduction in photosynthesis. Similarly, the observed reduction in AM colonization immediately after Hurricane Wilma may be the result of widespread defoliation and the corresponding reduction in photosynthates available to AM fungi. Reduced photosynthates may also help explain the reduction in AM colonization in September 2007, as this sampling date corresponded to the lowest percent carbon in plant roots.

Immediately following the hurricane, canopy openness increased in all seral stages, indicating widespread defoliation. Nearly $743 \mathrm{~g} / \mathrm{m}^{2}$ of litterfall was deposited on the forest floor and this input was rich in nitrogen because there was no opportunity for retranslocation of nutrients before leaf abscission (Vargas, unpublished data). We observed a rapid reduction in percent soil carbon after the hurricane in the late-seral stage. Because of the high nitrogen in litter, combined with high soil moisture and high soil temperature, rapid decomposition of hurricane litterfall occurred. Evidence for the rapid rate of decomposition comes from the high rates of soil respiration after the hurricane (Vargas and Allen 2008). As a result, evidence points to nitrogen functioning as an excessive nutrient shortly after the hurricane and being lost from the system via leaching of nitrate and gaseous losses (Agren and Bosatta 1988; Aber et al. 1989; Stoddard 1994; Peterjohn et al. 1996), resulting in higher soil $\delta^{15} \mathrm{~N}$ values (Martinelli et al. 1999). Although we did not directly measure pathways of nitrogen loss in this study, most pathways of nitrogen loss from ecosystems fractionate nitrogen isotopes leaving behind an enriched soil pool of $\delta^{15} \mathrm{~N}$ (Martinelli et al. 1999; Amundson et al. 2003) and we observed a significant increase in soil $\delta^{15} \mathrm{~N}$ values after the hurricane, consistent with loss of nitrogen via fractionating pathways.

Before the hurricane, soil $\delta^{15} \mathrm{~N}$ values in the earlyseral stage were significantly enriched in ${ }^{15} \mathrm{~N}$ compared to the other two seral stages, suggesting high nitrogen availability and an open nitrogen cycle in the 
early-seral stage. However, percent soil nitrogen was significantly lower in the early-seral stage prior to the hurricane compared to the other seral stages, indicating that nitrogen may not be in excess. The discrepancies between $\delta^{15} \mathrm{~N}$ values and percent soil nitrogen may, in part, be explained by greater proportion of legume species in the early relative to the late-seral stage. Previous examination of these plant roots has revealed the presence of nitrogen-fixing bacteria, suggesting that these species are capable of fixing atmospheric nitrogen (Allen and Rincon 2003). Consequently, high rates of nitrogen fixation in the early-seral stage may be coupled with a high loss of nitrogen through denitrification or leaching of ${ }^{14} \mathrm{~N}$, thereby creating the enriched soil $\delta^{15} \mathrm{~N}$ values.

Soil $\delta^{15} \mathrm{~N}$ values varied significantly among the different seral stages after the hurricane. In both the early- and mid-seral stages, we found no significant change in percent nitrogen or soil $\delta^{15} \mathrm{~N}$ values after the hurricane, indicating minimal loss of nitrogen from these seral stages. In contrast, there was a significant decrease in percent nitrogen and a significant increase in soil $\delta^{15} \mathrm{~N}$ values in the late-seral stage suggesting a significant loss of nitrogen from this seral stage. This loss of nitrogen may, in turn, help explain the arrested regeneration of aboveground forest canopy in the late-seral stage. Herbert et al. (1999) reported that soil nutrient supply can influence the rate of forest recovery after hurricane disturbance in Metrosideros polymorpha forests on Kauai, Hawaii. Two years after Hurricane Iniki, diameter increments of trees in added phosphorus treatments were significantly greater than diameter increments of trees in treatments lacking phosphorus fertilization. Forests on Kauai tend to be phosphorus limited (Treseder and Allen 2002), whereas phosphorus is relatively available at El Eden (Allen et al. 2003b, Allen and Rincon 2003), suggesting potentially greater limitation by nitrogen, but fertilization studies are needed to test the nature of nutrient limitation at El Eden.

In additional to the increased soil $\delta^{15} \mathrm{~N}$ values, we also observed a gradual, but insignificant, increase in root $\delta^{15} \mathrm{~N}$ values after the hurricane in the late-seral stage. The increase in root $\delta^{15} \mathrm{~N}$ values was most likely the result of direct uptake of ${ }^{15} \mathrm{~N}$ from enriched soil after the hurricane. However, another plausible explanation for the increase in root $\delta^{15} \mathrm{~N}$ values may be related to ectomycorrhizal (EM) fungi and their role in host plant nitrogen acquisition. Although tropical forests are primarily dominated by trees that form AM associations, we recently found evidence of EM fungi at our study site based on stable isotope composition of sporocarps (Hasselquist, unpublished data). The occurrence of EM fungi appears to predominate in the late-seral stage, with few to no observation of EM fungi in mid- and early-seral stages. During nitrogen uptake, EM fungi discriminate against ${ }^{15} \mathrm{~N}$ and transfer ${ }^{15} \mathrm{~N}$ depleted nitrogen to the host plant while retaining nitrogen that is enriched in ${ }^{15} \mathrm{~N}$ (Hobbie et al. 1999; Kohzu et al. 1999). Consequently, plants associated with EM fungi are often depleted in $\delta^{15} \mathrm{~N}$ as a result of a higher percentage of plant nitrogen being derived from EM fungi. Therefore, the relatively depleted pre-hurricane $\delta^{15} \mathrm{~N}$ values of plant roots in the late-seral stage may be the result of more nitrogen being derived from EM fungi, compared to early- and mid-seral stages where EM fungi are absent. Using methods of Hobbie and Hobbie (2006) and Macko et al. (1986) we have demonstrated (unpublished data) that EM fungi provide $\sim 40 \%$ of nitrogen in plants before the hurricane and $\sim 30 \%$ after the hurricane, which might explain the gradual increase in root $\delta^{15} \mathrm{~N}$ values after the hurricane. More research is needed to better understand the importance of EM fungi for host plant nitrogen acquisition in this forest as well as how EM fungi respond to large hurricane disturbances.

In conclusion, we found that the recovery of aboveground forest canopy after a large, infrequent disturbance is, in part, dependent on prior site history. In the early seral-stages, the canopy recovered to prehurricane conditions within 2 years after the pass of Hurricane Wilma, whereas aboveground forest canopy in the late-seral stage remained significantly reduced throughout the study. Moreover, this study also shows that constraints in aboveground recovery may be coupled to changes in belowground processes. In the late-seral stage, there appears to be a negative feedback among defoliation, fine roots, and soil nitrogen that, in part, may help explain the arrested regeneration of aboveground forest canopy. Immediately after Hurricane Wilma, we observed a significant increase in canopy openness and a shortterm pulse in soil nitrogen availability. We also observed a significant reduction in fine roots, which may have prevented trees from absorbing the pulse of soil nutrients after the hurricane, and as a result soil 
nitrogen was lost from the system through leaching and denitrification. Consequently, nitrogen availability may in turn limit aboveground productivity producing a feedback of reduced photosynthates for belowground processes such as fine root production. In contrast, because of the high proportion of legume species in the early- and mid-seral stages, nitrogen does not appear to be limiting aboveground productivity and recovery in these forests.

Across the Northern Yucatan Peninsula natural disturbances, human activities, and environmental gradients continue to interact in a complex and dynamic fashion. Over the past 50 years there has been an increase in the number of category III or greater hurricanes on the Northern Yucatan Peninsula (Boose et al. 2003). Although the recovery of forest structure is commonly thought to be relatively rapid following a hurricane disturbance (Chazdon 2003), future ecological research and management policies in seasonally dry tropical forests must address site history as well as belowground mechanisms influencing the recovery of aboveground forest structure after a large, infrequent disturbance.

Acknowledgments This research was supported by grants from NSF awarded to MF Allen (DEB-9981607, DEB0615427, EF-0410408) and from UC MEXUS awarded to N. J. Hasselquist. We thank El Eden Ecological Reserve for their continued support and access to their research facilities. We are also grateful to Rodrigo Vargas and Juan Castillo for their help in the field.

Open Access This article is distributed under the terms of the Creative Commons Attribution Noncommercial License which permits any noncommercial use, distribution, and reproduction in any medium, provided the original author(s) and source are credited.

\section{References}

Aber JD, Nadelhoffer KJ, Steudler P, Melillo JM (1989) Nitrogen saturation in northern forest ecosystems. Bioscience 39:378-386

Agren GI, Bosatta E (1988) Nitrogen saturation of terrestrial ecosystems. Environ Pollut 54:185-197

Allen MF (1991) The ecology of mycorrhizae. Cambridge University Press, Cambridge

Allen MF, Rincon E (2003) The changing global environment and the Lowland Maya: past patterns and current dynamics. In: Gómez-Pompa A, Allen MF, Fedick SL, Jimenez-Osornio JJ (eds) The Lowland Maya: three millennia at the human-wildland interface. Haworth, Binghamton, pp 13-29
Allen EB, Allen MF, Helm DJ, Trappe JM, Molina R, Rincon E (1995) Patterns and regulations of mycorrhizal plant and fungal diversity. Plant Soil 170:47-62

Allen EB, Rincon E, Allen MF, Perez-Jimenez A, Huante P (1998) Disturbance and seasonal dynamics of mycorrhizae in a tropical deciduous forest in Mexico. Biotropica 30:261-274

Allen EB, Allen MF, Egerton-Warburton L, Corkidi L, GómezPompa A (2003a) Impacts of early- and late-seral mycorrhizae during restoration in seasonal tropical forest, Mexico. Ecol Appl 13:1701-1717

Allen EB, Violi HA, Allen MF, Gómez-Pompa A (2003b) Restoration of tropical seasonal forest in Quintana Roo. In: Gómez-Pompa A, Allen MF, Fedick SL, JimenezOsornio JJ (eds) The Lowland Maya: three millennia at the human-wildland interface. Haworth, Binghamton, pp 587-598

Allen MF, Allen EB, Gómez-Pompa A (2005) Effects of mycorrhizae and nontarget organism on restoration of a seasonal tropical forest in Quintana Roo, Mexico: factors limiting tree establishment. Restor Ecol 13:325-333

Allen MF, Vargas R, Graham EA, Swenson W, Hamilton MP, Taggart M, Harmon TC, Rat'ko A, Rudel PW, Fulkerson B, Estrin DL (2007) Soil sensor technology: life within a pixel. Bioscience 57:859-867

Amundson R, Austin AT, Schuur EAG, Yoo K, Matzek V, Kendall C, Uebersax A, Brenner D, Baisden WT (2003) Global patterns of the isotopic composition of soil and plant nitrogen. Global Biogeochem Cycles 17:1031. doi: 10.1029/2002GB001903

Austin AT, Vitousek PM (1998) Nutrient dynamics on a precipitation gradient in Hawaii. Oecologia 113:519-529

Beard KH, Vogt KA, Vogt DJ, Scatena FN, Covich AP, Sigurdardottir R, Siccama TG, Crowl TA (2005) Structural and functional responses of a subtropical forest to 10 years of hurricanes and droughts. Ecol Monogr 75:345-361

Bellingham PJ (1991) Landforms influence patterns of hurricane damage: evidence from Jamaican montane forests. Biotropica 23:427-433

Blood ER, Anderson P, Smith PA, Nybro C, Ginsberg KA (1991) Effects of Hurricane Hugo on coastal soil solution chemistry in South Carolina. Biotropica 23: 348-355

Boose ER, Foster DR, Plotkin AB, Hall B (2003) Geographical and historical variation in hurricanes across the Yucatan Peninsula. In: Gómez-Pompa A, Allen MF, Fedick SL, Jimenez-Osornio JJ (eds) The Lowland Maya: three millennia at the human-wildland interface. Haworth, Binghamton, pp 495-515

Boucher DH (1990) Growing back after hurricanes; catastrophes may be critical to rain forest dynamics. Bioscience 40:163-166

Brokaw NVL, Walker LR (1991) Summary of the effects of Caribbean hurricanes on vegetation. Biotropica 23:442447

Canham CD (1988) An index for understory light levels in and around canopy gaps. Ecology 69:1634-1638

Chazdon RL (2003) Tropical forest recovery: legacies oh human impact and natural disturbances. Perspect Plant Ecol Evol Syst 6:51-71 
Cuevas E, Medina E (1988) Nutrient dynamics within Amazonian forests. II. Fine root growth, nutrient availability and leaf litter decomposition. Oecologia 76:222-235

Eom AH, Wilson GWT, Hartnett DC (2001) Effects of ungulate grazers on arbuscular mycorrhizal symbiosis and fungal community structure in tallgrass prairie. Mycologia 93:233-242

Fisher CR, Janis DP, Perry DA, Linder man RG (1994) Mycorrhiza inoculum potentials in tropical secondary succession. Biotropica 26:369-377

Foster DR, Flute M, Boose ER (1999) Human or natural disturbance: landscape dynamics of the tropical forests of Puerto Rico. Ecol Appl 9:555-572

Frangi JL, Lugo AE (1991) Hurricane damage to a flood plant forest in the Luquillo Mountains of Puerto Rico. Biotropica 23:324-335

Gange AC, Bower E, Brown VK (2002) Differential effects of insect herbivory on arbuscular mycorrhizal colonization. Oecologia 131:103-112

Gómez-Pompa A (1992) Traditional Management of natural resources for the conservation of biodiversity and the development of sustainable agriculture for the Maya region. Riverside, USA. John D. and Catherine T Macarthur Foundation. University of California, CA, USA

Gómez-Pompa A, Allen MF, Fedick SL, Jimenez-Osornio JJ (2003) The Lowland Maya area: three millennia at the human-wildland interface. Haworth, Binghamton

Guadarrama P, Alvarez-Sanchez FJ (1999) Abundance of arbuscular mycorrhizal fungi spores in different environments in a tropical rain forest, Veracruz, Mexico. Mycorrhiza 8:267-270

Handley LL, Raven JA (1992) The use of natural abundance of nitrogen isotopes in plant physiology and ecology. Plant Cell Environ 15:965-985

Handley LL, Scrimgeour CM (1997) Terrestrial plant ecology and ${ }^{15} \mathrm{~N}$ natural abundance: the present limits to interpretation for uncultivated systems with original data from a Scottish old field. Adv Ecol Res 27:133-212

Herbert DA, Fownes JH, Vitousek PM (1999) Hurricane damage to a Hawaiian forest: nutrient supply rate affects resistance and resilience. Ecology 80:908-920

Hobbie JE, Hobbie EA (2006) ${ }^{15} \mathrm{~N}$ in symbiotic fungi and plants estimates nitrogen and carbon flux rates in arctic tundra. Ecology 87:816-822

Hobbie EA, Macko SA, Shugart HH (1999) Insights into nitrogen and carbon dynamics of ectomycorrhizal and saprotrophic fungi from isotope evidence. Oecologia 118:353-360

Hodge A (2004) The plastic plant: root response to heterogeneous supplies of nutrients. New Phytol 162:9-24

Högberg P (1997) ${ }^{15} \mathrm{~N}$ natural abundance in soil-plant systems. New Phytol 137:179-203

Huante P, Rincon E, Allen EB (1993) Effects of vesiculararbuscular mycorrhizae on seedling growth of four tree species from the tropical deciduous forest in Mexico. Mycorrhiza 2:141-145

Janos DP (1980a) Vesicular-arbuscular mycorrhizae affect lowland tropical rain-forest plant-growth. Ecology 61: $151-162$

Janos DP (1980b) Mycorrhizae influence tropical succession. Biotropica 12:56-64
Johnson NC, Wedin DA (1997) Soil carbon, nutrients, and mycorrhizae during conversion of dry tropical forest to grassland. Ecol Appl 7:171-182

Kiers ET, Lovelock CE, Krueger EL, Herre EA (2000) Differential effects of tropical arbuscular mycorrhizal inocula on root colonization and tree seedling growth: implication for tropical forest diversity. Ecol Lett 3:106-113

Kohzu A, Yoshioka T, Ando T, Takahashi M, Koba K, Wada E (1999) Natural ${ }^{13} \mathrm{C}$ and ${ }^{15} \mathrm{~N}$ abundance of field-collected fungi and their ecological implications. New Phytol 144: 323-330

Koske RE, Gemma JN (1989) A modified procedure for staining roots to detect VA mycorrhizas. Mycol Res 92:486-505

Lodge DJ, McDowell WH (1991) Summary of ecosystem-level effects of Caribbean hurricanes. Biotropica 23:373-378

Lodge DJ, Scatena FN, Asbury CE, Sanchez MJ (1991) Fine litterfall and related nutrient inputs resulting from Hurricane Hugo in subtropical wet and lower montane rain forests of Puerto Rico. Biotropica 23:336-342

Lugo AE, Scatena FN (1995) Ecosystem-level properties of the Luquillo Experimental Forest with emphasis on the tabonuco forest. In: Lugo AE, Lowe C (eds) Tropical forests: management and ecology. Ecological Studies, vol 112. Springer, New York, p 59-108

Macko SA, Fogel-Estep ML, Engle MH, Hare PE (1986) Kinetic fractionation of stable nitrogen isotopes during amino acid transamination. Geochemica et Cosmochemica Acta 50:2143-2146

Martinelli LA, Piccolo MC, Townsend AR, Vitousek PM, Cuevas E, McDowell W, Robertson GP, Santos OC, Treseder K (1999) Nitrogen stable isotopic composition of leaves and soil: tropical versus temperate forests. Biogeochemistry 46:45-65

McGonigle TP, Miller MH, Evans DJ, Fairchild GL, Swan JA (1990) A new method which gives an objective measure of colonization of roots by vesicular-arbuscular mycorrhizal fungi. New Phytol 115:495-501

Nadelhoffer KJ, Fry B (1994) Nitrogen isotope studies in forest ecosystems. In: Lajtha K, Michener R (eds) Stable isotopes in ecology and environmental science. Blackwell, Oxford, pp 22-44

Newman EI (1966) A method of estimating the total length of root in a sample. J Appl Ecol 3:139-145

Parrotta JA, Lodge DJ (1991) Fine root dynamics in a subtropical wet forest following hurricane disturbance in Puerto Rico. Biotropica 23:343-347

Pascarella JB, Aide TM, Zimmerman JK (2004) Short-term response of secondary forests to hurricane disturbance in Puerto Rico, USA. For Ecol Manag 199:379-393

Peterjohn WT, Adams MB, Gilliam FS (1996) Symptoms of nitrogen saturation in two central Appalachian hardwood forest ecosystems. Biogeochemistry 35:507-522

Piccolo MC, Neill C, Melillo JM, Cerri CC, Steudler PA (1996) ${ }^{15} \mathrm{~N}$ natural abundance in forest and pasture soils of the Brazilian Amazon Basin. Plant Soil 182:249-258

Read DJ (1991) Mycorrhizas in ecosystems. Experientia 47:376-391

Scatena FN, Silver W, Siccama T, Johnson A, Sanchez MJ (1993) Biomass and nutrient content of the Bisley Experimental Watersheds, Luquillo-Experimental-Forest, 
Puerto Rico, before and after Hurricane-Hugo, 1989. Biotropica 25:15-27

Schutlz GP (2005) Vascular flora of the El Eden ecological reserve, Quintana Roo, Mexico. J Torrey Bot Soc 132:311-322

Schuur EAG, Matson PA (2001) Net primary productivity and nutrient cycling across a mesic wet precipitation gradient in Hawaiian montane forest. Oecologia 128:431-442

Silver WL, Vogt KA (1993) Fine root dynamics following single and multiple disturbances in a subtropical wet forest ecosystem. J Ecol 81:729-738

Stark N (1971) Nutrient cycling pathways and litter fungi. Bioscience 22:355-360

Stark N, Jordan CF (1978) Nutrient retention by the root mat of an Amazonian rain forest. Ecology 59:434-437

Stark N, Spratt M (1977) Root biomass and nutrient storage in rain forest Oxisols near San Carlos de Rio Negro. Tropical Ecol 18:1-9

Steudler PA, Melillo JM, Bowden RD, Castro MS (1991) The effects of natural and human disturbance on soil nitrogen dynamics and trace gas fluxes in a Puerto Rican wet forest. Biotropica 23:356-363

Stoddard JL (1994) Long-term changes in watershed retention of nitrogen. In: Baker LA (ed) Environmental chemistry of lakes and reservoirs. Advances in Chemistry, vol 273. ACS, Washington, DC, p 223-284

Tanner EVJ, Kapos V, Healey JR (1991) Hurricanes effects on forest ecosystems in the Caribbean. Biotropica 23:513521

Templer PH, Arthur MA, Lovett GM, Weathers KC (2007) Plant and soil abundance $\delta^{15} \mathrm{~N}$ : indicators of relative rates of nitrogen cycling in temperate forest ecosystems. Oecologia 153:399-406

Thompson J, Lugo AE, Thomlinson J (2007) Land use history, hurricane disturbance, and the fate of introduced species in a subtropical wet forest in Puerto Rico. Plant Ecol 192:289-301

Treseder KK, Allen MF (2002) Direct nitrogen and phosphorus limitation of arbuscular mycorrhizal fungi: a model and field test. New Phytol 155:507-515

Treseder KK, Cross A (2006) Global distribution of arbuscular mycorrhizal fungi. Ecosystems 9:305-316

Turner MG, Dale VH (1998) Comparing large, infrequent disturbances: what have we learned? Ecosystems 1:493-496
Uriate M, Rivera LW, Zimmerman JK, Aide TM, Power AG, Flecker AS (2004) Effects of land use history on hurricane damage and recovery in a neotropical forest. Plant Ecol 174:49-58

Vargas R, Allen MF (2008) Diel patterns of soil respiration in a tropical forest after Hurricane Wilma. J Geophys Res Biogeosci 113:G03021. doi:03010.01029/02007JG000620

Vargas R, Allen MF, Allen EB (2008) Biomass and carbon accumulation in a fire chronosequence of a seasonally dry tropical forest. Glob Chang Biol 14:109-124

Vargas R, Hasselquist H, Allen EB, Allen MF (2009) Effects of hurricane disturbance on aboveground forest structure, arbuscular mycorrhizae and belowground carbon in a restored tropical forest. Ecosystems (in review)

Walker LR (1991) Tree damage and recovery from Hurricane Hugo in Luquillo Experimental Forest, Puerto Rico. Biotropica 23:379-385

Wearn JA, Gange AC (2007) Above-ground herbivory causes rapid and sustained changes in mycorrhizal colonization of grasses. Oecologia 153:959-971

Weaver PL (1986) Hurricane damage and recovery in the montane forests of the Luquillo Mountains of Puerto Rico. Caribbean J Sci 22:53-70

Went FW, Stark N (1968) Mycorrhiza. Bioscience 18:10351039

Whigham DF, Olmstead I, Cano EC, Harmon ME (1991) The impact of Hurricane Gilbert on trees, litterfall, and woody debris in a dry tropical forest in the Northeastern Yucatan Peninsula. Biotropica 23:434-441

Whigham DF, Olmsted I, Cano EC, Curtis AB (2003) Impacts of hurricanes on forests of Quintana Roo, Yucatan Peninsula, Mexico. In: Gómez-Pompa A, Allen MF, Fedick SL, Jimenez-Osornio JJ (eds) The Lowland Maya: three millennia at the human-wildland interface. Haworth, Binghamton, pp 193-216

Yih K, Boucher DH, Vandermeer JH, Zamorra Z (1991) Recovery of the rain forest of southeastern Nicaragua after destruction by Hurricane Joan. Biotropica 23:106113

Zimmerman JK, Willig MR, Walker LR, Silver WL (1996) Introduction: disturbance and Caribbean ecosystems. Biotropica 28:414-423 